\title{
Education in Learning Religious Education in College Education in Palopo City
}

\author{
Yunus \\ Eresha College of Computer Science Management \\ Jl. Raya Puspiptek, Buaran, Kec. Serpong \\ Nurhang542@gmail.com
}

\begin{abstract}
Cultivating awareness of the multicultural dimension in a plural and multicultural society through education is urgent because education is a potential entry point to instill an appreciation for diversity due to ethnicity, religion, gender, and family economic background and others. college student. This study aims to describe the cultural values of Bugis in Islamic education that develop in universities in Palopo City. In research using qualitative. The culture of siri 'in religious learning from students' attitude of discipline and responsibility. Discipline and student responsibility to maintain self-esteem and dignity of students which are a reflection of the culture of siri 'which functions as the spirit of students in the value education process. The concept of siri learning in education provides respectful values such as Sipakatau (giving information), Sipakalebbi (Mutual Respect), Sipakaingge (Reminding each other), Sipakatou (Sharing). Bugis culture has a sense of love and affection for others which is shown by proverbs such as Mali siparappe, rebba sipatokkong, malilu sipakainge (other people are taken away, helped, some fall, are helped to wake up, others come out of the norm to be reminded / repent). Bugis people are fellow human beings, let alone fellow humans. So that Bugis cultural education is in line with the values of pluralism that grow and develop in Indonesia.
\end{abstract}

Keywords : Siri's Culture, Islamic Religious Learning

\begin{abstract}
Abstrak
Penanaman kesadaran akan dimensi multikultural di tengah masyarakat yang plural dan multikultural melalui pendidikan menjadi urgen sebab pendidikan merupakan pintu masuk potensial untuk menanamkan apresiasi terhadap adanya keragaman baik karena latar belakang suku, agama, jenis kelamin, dan latar belakang ekonomi keluarga dan lain-lain di kalangan mahasiswa. Penelitian ini bertujuan untuk mengambarkan nilai budaya Bugis dalam pendidikan Islam yang berkembang di perguruan tinggi di Kota Palopo. Dalam penelitian menggunakan penelitian kualitatif. Budaya siri 'dalam pembelajaran agama tercermin dari sikap peserta didik melalui disiplin dan tanggung jawab. Kedisiplinan dan tanggung jawab peserta didik untuk menjaga harga diri, martabat peserta didik yang merupakan cerminan budaya siri 'yang berfungsi sebagai ruh peserta didik dalam proses pendidikan nilai. Konsep pembelajaran siri dalam pendidikan memberikan nilai-nilai penghormatan seperti Sipakatau (saling memberi informasi), Sipakalebbi (Saling Menghormati), Sipakaingge (Saling Mengingatkan), Sipakatou (Berbagi). Budaya Bugis memiliki rasa cinta dan kasih sayang kepada orang lain yang ditunjukkan oleh peribahasa seperti Mali siparappe, rebba sipatokkong, malilu sipakainge (orang lain dibawa pergi, dibantu, ada yang jatuh dibantu bangun, yang lain keluar dari norma diingatkan/bertobat). Orang Bugis menghargai perdamaian, senang membantu sesama, apalagi jika mereka sesama manusia. Sehingga pendidikan budaya Bugis sejalan dengan nilai-nilai pluralisme yang tumbuh dan berkembang di Indonesia.
\end{abstract}

Kata Kunci: Budaya Siri', Pembelajaran Pendidikan Islam

Copyright (C) 2021 Yunus

$\triangle$ Corresponding author: Yunus

Email Address: Nurhang542@gmail.com (Jl. Raya Puspiptek, Buaran, Kec. Serpong)

Received 28 Januari 2020, Accepted 30 Desember 2020, Published 30 Desember 2020

\section{INTRODUCTION}

Culture in Indonesia, on the basis of upholding togetherness and mutual cooperation, is linked to spirituality and culture(Herdiansah, Sumadinata, Padjajaran, \& Padjajaran, 2019; Kersten, 2009; 
Yusri, 2015). The application of cultural values in every aspect of life to ward off various cultural issues of anarchism, materialism, secularism, and radicalism, even the issue of terrorism which threatens the integrity of the Unitary State of the Republic of Indonesia (NKRI) (Musanna, 2010). Thus, in the future culture becomes an agenda for actualizing and preserving cultural values such as siri 'in the form of the Bugis tradition which contains educational values such as being ashamed of doing actions that are not in accordance with Islamic norms. Local wisdom is a view of life and as social capital for the Bugis community which becomes a reference in household and community life(A. S. Rustan \& Cangara, 2011; Syarif, Sumarmi, \& Astina, 2016).

The values contained in the pangngadereng element, referring to lontara among the BugisMakassar, are almost the same, both in spirit and spirit, as well as in the form of expression which is integrated in Islamic law. This can be found in Lontarak Latoa Bone, Rapanna Gowa, Pappasengna Wajo, the phrase La-Waniaga Arung Bila in Soppeng and others, which are easy to know because religion on the one hand is a belief system embraced and manifested by its adherents in religious actions(Darmawati, 2014). in society in an effort to respond to what is felt and believed to be sacred and holy.

Religion is also understood as a system that regulates the relationship between humans and God, humans and other humans and even humans and their environment in the form of religious institutions and symbols(Busyairi, 2017; RAHMAN, 2008; Y. Yunus \& Salim, 2019). Meanwhile, culture or culture is interpreted as a pattern for behavior which consists of a series of rules, recipes, plans and instructions through symbols used by humans to regulate their behavior. If this is the case, culture is not something that is born naturally, but is composed by humans as a result of human work in the form of ideas, concepts, behavior and social institutions.

The Bugis ethnic group is an ethnic group in Indonesia which belongs to the large Austronesian family who inhabit the southern part of the island of Sulawesi. Currently, their population is more than three million people. Some others have migrated out of the territory of their ancestors.

Political behavior is closely related to the culture and language of an ethnicity(Nurhasim, 2010; Yustiningrum \& Ichwanuddin, 2015). These two things cannot be separated from one another. Language is a reflection of culture. Conversely, culture is a value, a principle that can be believed to be true in a language-speaking society, and can serve as a guide in interacting and communicating, including the culture of the Bugis community in South Sulawesi Province. In the 2013 Curriculum implementation strategy, it was developed based on the principle that students have a central position to develop their competence so that they become human beings who believe and believe in God who is one, noble, healthy, knowledgeable, creative, independent and become democratic and responsible citizens(Meals \& Washburn, 2015; E. Rustan, Hanifah, \& Kanro, 2018; Tanis, 2013).

Therefore, one thing that is important to do no matter how hard it is to restore human development on the basis of perfect Islamic principles and noble morals because humans are created 
to have great character. In the teacher's effort to implement the culture of siri 'in children starting from the family and school environment. As it is known, the education and guidance given to children when they are children will have a strong influence in their soul and society, because this period is indeed a period of preparation and direction(Yunus, Nurseha, 2020).

The siri 'culture is a Bugis culture that has a positive influence on the formation of the personality of each individual. If this cultural value is instilled in every student who is in a family, especially in a student, the class internal control system will be more effective. The implementation of siri 'culture can be a reference in reconstructing the internal control model that has been applied so far(Ismail Suwardi Wekke, Arhanuddin Salim, 2018).

Someone who imitates good deeds will be classified as righteous as well. Likewise, someone who imitates the actions of a fasiq person will be classified as a fasiq person as well. Thus, copying the strategy of another government that is positive in nature is much better than copying the strategy of another government which is negative in nature. Apart from these three cultures, there is still one Bugis culture that can have a positive influence on life, namely the siri 'culture.

Local wisdom contains values and norms that prohibit a person from doing certain actions. Because violating the prohibition results in serious consequences for the violator. The implementation of a siri 'culture in every student and society can help increase compliance. Although most modern societies consider the implementation of this culture to be out of date, those who still preserve this culture consider it to be one of the most effective rules in preventing someone from committing deviations.

Culture tends to prohibit someone from doing an act that is not in accordance with religious norms(Bland, 2019). Violation of the prohibition results in severe consequences for the violator. The culture of siri 'must exist in every student because it can help increase the compliance of employees with government regulations so that the effectiveness of the control system. Therefore, in the present era, the concept of siri 'is considered only as a culture in the past. The degradation of the siri 'value is due to cultural inheritance that is not well integrated into formal education.

Apart from formal education, it is also informal education, as a result of busy parents due to the economic demands of the family. This problem is in stark contrast to Islamic education, as early education for children. Therefore, siri 'cultural inheritance must be well integrated into formal education as well as maximizing informal education.

Reinterpretation of the meaning of siri 'for revitalization is useful for the development of civilization in global interactions, because it functions as a motivator, social control, a sense of responsibility and a social dynamist. If siri'i is a self-esteem bet, then that self-esteem must be raised through hard work, achievement, pioneering spirit and always being success oriented. Siri 'and Pacce are two moral attitudes that maintain stability and have a harmonization dimension, so that the social order or Pangadereng (traditional core customs) runs dynamically(Nurnaningsih, 2015). 
The siri 'value of the cultural system as a guideline that regulates people's behavior can be studied through: customs, norm systems, ethical rules, moral rules, rules of manners, life views and personal ideology. Physically, it is strongly influenced by the socio-cultural factors of the local community. Parsons's theory which prioritizes system and function analysis will be able to explain in depth the various conditions that support the preservation and continuity of culture in the social system of society, even though a culture is no longer a political system or a formal institution.

The element of siri 'value for Bugis culture is closely related to the elements of norms/rules. The cultural concept expressed by Rapoport (2005) in relation to the formation of the built environmentthat to see the expression of cultural values specifically in addition to seeing the lifestyle of the people, it also looks at the images, patterns, and meanings understood by the community which can then be manifested in the form of certain agreed norms or rules. The elements of values and norms that are understood by society are also very much influenced by the presence of religion. Religion is an institution that can produce tremendous power and knowledge, especially in a society like Indonesia. The presence of religion will regulate every individual and society through uniformity, both behavior, language, dress, and ritual

\section{METHOD}

This study uses a qualitative method. Qualitative research (qualitative research) is an umbrella concept that includes several research format help understand and explain the meaning of social phenomena from existing natural settings. The location of this research is at Andi Djemma University. The approach used in this study includes an ethnopedagogical approach. So the authors feel the need to put forward ethnopedagogy as a practice of education based on local wisdom in various domains and emphasize local knowledge or wisdom as a source of innovation and skills that can be empowered for the welfare of society, namely local wisdom is related to how knowledge is produced, stored, applied, managed and passed on

\section{RESULT}

\section{AND DISCUSSION}

The value of siri 'is a cultural system as a guideline that regulates people's behavior, which can be studied through customs, norms systems, ethical rules, moral rules, rules of manners, life views and personal ideology. Physically, it is strongly influenced by the socio-cultural factors of the local community. Parsons's theory which prioritizes system and function analysis will be able to explain in depth the various conditions that support the preservation and continuity of culture in the social system of society, even though a culture is no longer a political system or a formal institution. The conditions that support the continuity of culture according to the observations are three: (1) cultural conditions, (2) social conditions, and (3) material conditions. In adapting to the environment, a person 
brings with him the norms that govern behavior and the role he plays (Habermas, 1981). The built environment and architecture that develop from the community's traditions are a direct reflection of the culture, the values adopted, the habits and desires of the people.

Cultivation and development of values in a person. Values as an aid to students in order to realize and experience values and place them integrally in their whole life. The cultivation of values in college is divided into two, namely:

1) Cultivating personal character values

Bugis cultural values, ada tongeng, lempu (honest), and getteng (firm). As for what is meant by no tongeng means true speech. Words and deeds are always the same. There are tongeng must be owned by students.

Ada tongeng is a good and true word, in this case a king must have this value, so that when he speaks, his words are true and always associated with a clean heart. Between words and actions are always the same or known as taro ada taro gau.

The value of lempuk is the value of honesty or in Indonesian it means straight, not bent. Straight people are indispensable in leading a country or society. This value was owned by a king / pajung during the Kedatuan Luwu era, so that the community was safe and prosperous.

Lempu It is honesty, it is very important that leaders have at this time, because the value of lempu is very rarely owned by today's leaders. Even though honesty is the key to all human actions. If a leader has an honest character, then the community will be prosperous, because all policies are made based on honesty.

Getteng is the firm nature of a person, in this case not easily swayed and swayed, sticking to his stance or being consistent. Nature is a trait that all kings must have in their leadership. If a leader does not have a getteng nature, then society is not organized because the leader has a strategy in managing society(S. Yunus, 2020).

These values must be possessed by a leader, but it would be great for every society to appreciate the value of tonging (telling the truth), because this is important in people's lives even in the world of education and Islam forbids us to lie as is done to leaders.

\section{2) Cultivating social character values}

The emergence of encouragement and awareness to promote and implement local wisdom cannot be separated from the strong desire of various Bugis communities. This desire is not only at the social level, but also for students, including in practice at school. Even though today, the cultural learning system in Indonesia has brought many positive changes, on the other hand, we cannot close our eyes that various problems still occur in its implementation. Therefore, in order to produce one of the highest cultures in the siri 'na pesse culture, actors are not only supported by a mere legal umbrella, but ethical / moral aspects include the values of siri' na pesse which are part of the local wisdom of the local community. . 
According to Errington, by siri 'a person can avoid all actions that destroy one's self-respect and dignity. On that basis, it is only natural that siri 'and pesse are two moral attitudes that maintain stability and have a harmonious dimension.

In the concept of siri ', in essence, people lead people who are obedient and obedient in religion. That is why the Bugis people who enforce their siri' will avoid despicable acts. He feels embarrassed when he violates norms, both social norms and even violations of religious norms. Because siri 'is ashamed of violating religious and social norms, it shows that the siri culture' can be a spirit for people to always obey His God and always have good relationships with fellow humans.

Learning is the result of social interaction which is full of social values and local wisdom. On that basis, the application of Bugis local wisdom education must consider the social environment in which the actors practice these local wisdom values. It was also emphasized by Blumer that individuals individually or collectively act towards their environment on the basis of the meaning which Garfinkel and Sacks call social facts which are also the basis for implementing the actions of the actors, including in the context of compiling learning programs in schools.

In enculturation and socialization, siri 'is attached to the person of each individual. So consciously, the values of Siri 'Na Pesse have been practiced in all lines of daily life. As part of the supporter of local wisdom, budget actors should adhere to the values of Siri 'Na Pesse so that the resulting budget will also produce programs and activities that are full of Siri' Na Pesse, namely the concept of budgeting that puts Siri 'values(Nurnaningsih, 2015). Na Pesse as the base. The values referred to include tongeng (truth), getteng (firmness), lempu '(honesty), and adele' (justice), as well as other local wisdom values. Departing from the ideas and research motivation stated above, the authors feel interested in responding to the views expressed by Lopa (2005) to rediscover the concept of Bugis wisdom values which are the foundation in everyday life, including in the context of programming at schools.

From the concept above, thenit can be concluded from the description above; First, the emergence of the phenomenon of decreasing noble character among students; second, there is no educational model that can create a tolerant attitude that is able to accommodate all kinds of diversity and creates a pluralist character of students in schools, in accordance with the religious and cultural values of the Indonesian nation. Thus, it is necessary to find and formulate an effective cultural education model that can be implemented in every educational path (formal, non-formal, and informal). Here the author is in the essence of education which cannot be separated from the conditions of the pluralistic society or nation of Indonesia. Each of the diverse ethnic groups of Indonesia, of course, has its own norms, has its own noble cultural values, and have local advantages or have local wisdom (local knowledge or local wisdom) itself. As for application in class, as follows:

\section{Application of Luwu cultural local wisdom at UNANDA Palopo}




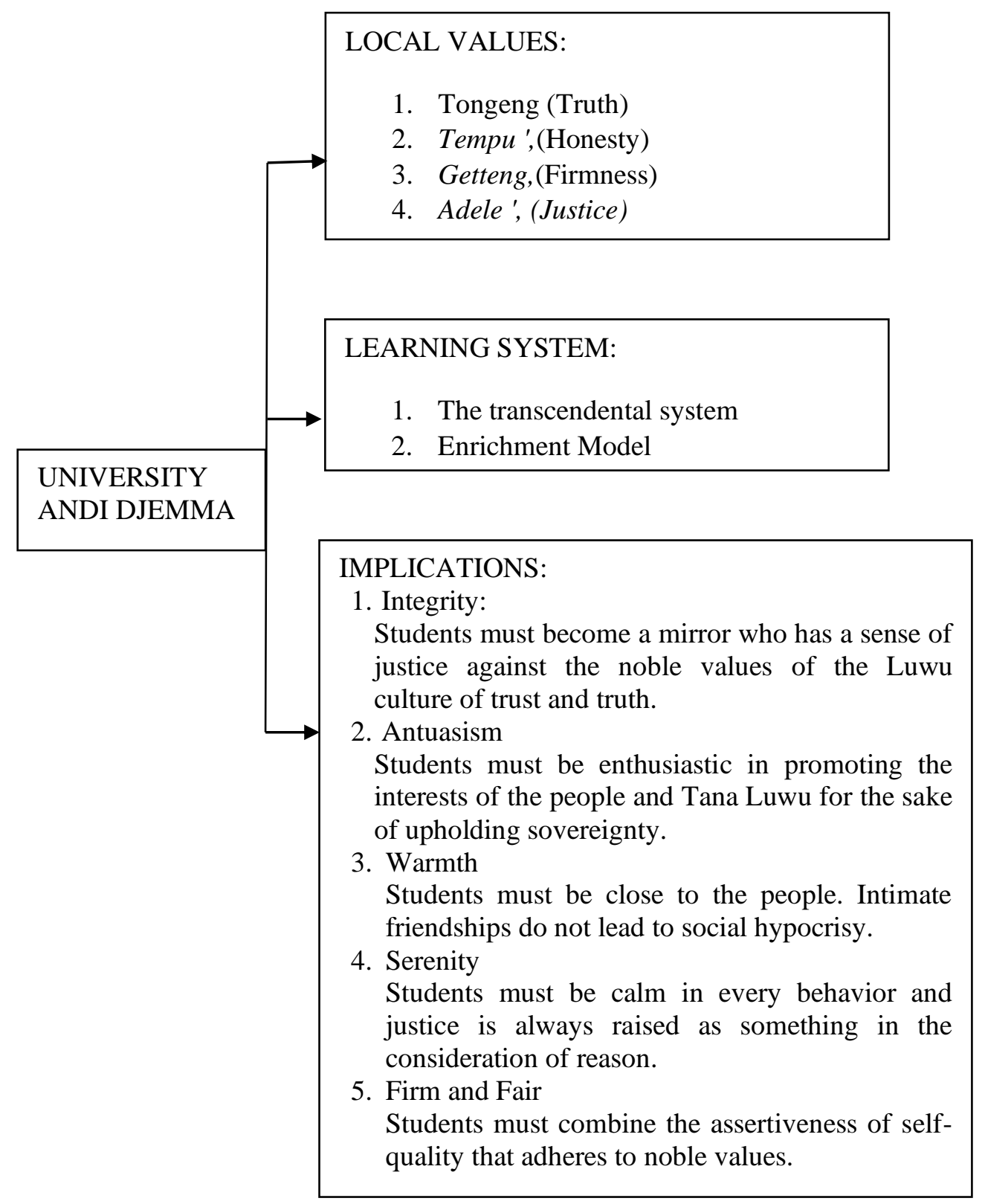

The principles of local wisdom education applied on campus do provide a complete understanding to students to be able to deeply respects the cultural, faith, religious, or secular, always deepen respect and attention to matters relating to beliefs, religions and social phenomena. On the other hand, the comments of a UNANDA graduate need attention. He said that this social influence could be seen from the graduates when they returned to society. They can campaign for a peaceful life in the midst of different beliefs in society. Being a driving force for the progress of religious communities, as well as being an intermediary for diversity problems that can result in conflicts between religions and cultures (Salwan, 2019).

Student mbe a driving force for the progress of religious communities and an intermediary for the emergence of religious friction. Must be the vision of this campus life. What has been obtained while attending lectures on campus. This can be a provision for building synergy between religious 
communities. These alumni are expected not only to replicate socio-cultural realities, but also to recreate socio-cultural buildings that tend to be unfriendly to cultural or religious differences.

Religious tolerance seems like a matter of course. However, the practice sometimes faces various obstacles. The role of a Muslim in tolerating followers of other religions such as Seko students and our brother from Tator (Tau Toraja)(Anggraini, 2016; Rahim, 2017; Tyson, 2008). Islam, as it is understood, is a friendly Islam. Islam which provides space for the development of other religions to grow and develop. This tolerance that is practiced has manifested itself into an inclusive attitude in religion. This is what is known as acknowledging differences. Precognition of differences. Without having to be trapped in the right or wrong judgment of other people's beliefs.

Apart from functioning as agents of cultural socialization, higher education also functions as a means of cultivating social solidarity which leads to mutual trust between fellow citizens and jointly realizing democracy in Palopo City(Mubarok, 2018). According to Putnam (1993) mutual trust is a very important element of social capital. Democracy that is built in society, the social interactions are very complex. Cooperation and coordination in society is almost impossible to materialize, if it is only based on the knowledge and rational calculations of individual community members, because individuals have limited information and knowledge to make decisions.

Mutual trust (trust) helps people to solve every problem, and because of this collective collaboration, allows the community to interact, even though they sometimes do not have sufficient knowledge. The education process in tertiary institutions aims to transmit values and norms that come from culture, in the form of respecting individual rights and fostering work morale.

According to the author, from the theological point of view, the discourse of pluralism and culture that has been formulated by the characters is still relevant and adequate to be an alternative viewpoint in understanding the pluralistic reality. With a pluralist paradigm and attitude, a person actually has religious views and attitudes that are authentic, at the same time moderate and wise (humanist).

\section{CONCLUSION}

Siri 'is "shame" (life / life) and "self-respect". If seen carefully, it contains the meaning of the law of cause and effect (causality). Humans are "ashamed" in the sense that they are not pappaka sirisiri because someone is defended, on the other hand someone maintains his pride because he is "embarrassed".Siri ' can function as the spirit of students in the educational process. The value of Islamic education which is summarized in the values of divinity (ilahiyah), humanity, and experience have in common with the value of siri 'which is summarized in the elements of siri': pajjama, lempu, getteng, and sipakatau. However, the value of siri does not cover the overall value of Islamic education.

But Local wisdom actually aims to guide students to be able to build a life order that positions humans as noble creatures, namely sipakatau. Likewise, the term sipakalebbi means to honor each 
other. All human beings feel happy when they are respected and glorified by each other, even all religious teachings teach mutual respect and honor among fellow students. Mutual respect and respect have been carried out by the Bugis community for a long time, especially by those who are younger to the older ones.

\section{REFERENCESS}

Anggraini, D. (2016). Interaksi Sosial Orang Tanah Toraja Pada Masyarakat Lokal Di Kabupaten Kolaka. KANAL: Jurnal Ilmu Komunikasi, 2(1), 1. https://doi.org/10.21070/kanal.v2i1.272

Bland, B. (2019). Politics in Indonesia: Resilient elections, defective democracy, (April), 23. Retrieved from https://www.lowyinstitute.org/sites/default/files/Bland_Politics in Indonesia_WEB_0.pdf

Busyairi, M. (2017). Education Unit Transformation for Maintain Its Existence in Islamic Boarding School (Multi-case Study on Tebuireng Islamic Boarding School, Gading Islamic Boarding School Malang, and Sidogiri Islamic Boarding School Pasuruan). Journal of Education and Practice, 8(5), 56-64.

Darmawati, B. (2014). Kearifan sistem pemerintahan puang rimaggalatung dalam Lontarak Bugis, 112.

Errington, Shely, Siri': Siri', Darah dan Kekuasaan Politik Dalam Kerajaan Luwu' Zaman Dulu. Bingkisan, seri Baru, 1 (2). (1977)

Habermas, J. (1981). Talcott Parsons: Problems of theory construction. Sociological Inquiry, 51(3-4), 173-196.

Herdiansah, A. G., Sumadinata, W. S., Padjajaran, U., \& Padjajaran, U. (2019). Indonesia 's political culture in the new digital age: A preliminary discussion Budaya politik Indonesia di era digital baru : Suatu diskusi pendahuluan. Masyarakat, Kebudayaan Dan Politik, 32(4), 378-389.

Ismail Suwardi Wekke, Arhanuddin Salim, Y. S. (2018). Pendidikan Karakter Dalam Masyarakat Bugis. Ijtimaiyya: Jurnal Pengembangan Masyarakat Islam, 11(1), 41-62. https://doi.org/10.24042/ijpmi.v11i1.3415

Kersten, C. (2009). Indonesiaâ€ TM Sew Muslim Intellectuals. Religion Compass, 3(6), 971-985. https://doi.org/10.1111/j.1749-8171.2009.00187.x

Lopa, Baharuddin, Siri dalam Masyarakat Mandar. Dalam Siri' dan Pesse: Harga Diri Bugis, Makassar, Mandar, dan Toraja, Makassar, Pustaka Refleksi, 2005.

Meals, A., \& Washburn, S. (2015). Achieving Next Generation Science Standards Through Agricultural Contexts: A Delphi Study of Outdoor Education Experts. Journal of Agricultural Education, 56(4), 1-16. https://doi.org/10.5032/jae.2015.04001

Mubarok, H. (2018). Demokrasi , Politik Identitas, dan Kohesi Sosial: Peluang dan Tantangan Strategi Dakwah untuk Menghalau Provokasi Politik di Indonesia Democracy , Identity Politics , and Social Cohesion: Opportunities and Threats of Dakwah Strategy in Countering Polit. Jurnal Bimas Islam, II(II), 365-400.

Musanna, A. (2010). Revitalisasi Kurikulum Muatan Lokal Untuk Pendidikan Karakter Melalui Evaluasi Responsif. Jurnal Pendidikan Dan Kebudayaan, 16(9), 245. https://doi.org/10.24832/jpnk.v16i9.516

Nurhasim, M. (2010). Konflik dalam Pilkada Langsung: Studi tentang Penyebab dan Dampak Konflik. Jurnal Penelitian Politik, 7(2), 105-117. 
Nurnaningsih, N. (2015). Rekonstruksi Falsafah Bugis dalam Pembinaan Karakter: Kajian Naskah Paaseng Toriolo Tellumpoccoe. Jurnal Lektur Keagamaan, 13(2), 393. https://doi.org/10.31291/jlk.v13i2.232

Putnam, Robert. Making Democracy work: Civic Tradition in Modern Italy. Princenton: NJ: Princenton Universuty Press. 1993.

Rahim, A. . R. (2017). Mengenal Lebih Dekat Tana Toraja. Retrieved from http://gln.kemdikbud.go.id/glnsite/mengenal-lebih-dekat-tana-toraja/

RAHMAN, N. (2008). Agama, tradisi dan kesenian dalam manuskrip La Galigo. SARI: Jurnal Alam Dan Tamadun Melayu, 26, 213-220.

Rapoport, House Form and Culture, Prentice-Hall, Inc, Englewood Cliffs, New York: N.J, 2005.

Rustan, A. S., \& Cangara, H. (2011). PERILAKU KOMUNIKASI ORANG BUGIS DARI PERSPEKTIF ISLAM. Jurnal Komunikasi KAREBA (Vol. 1).

Rustan, E., Hanifah, N., \& Kanro, B. (2018). De-radicalization in the Implementation of Islamic Education Curriculum in SMA Masamba South Sulawesi. Dinamika Ilmu, 18(2), 271-283. https://doi.org/10.21093/di.v18i2.1338

Syarif, E., Sumarmi, S., \& Astina, I. K. (2016). Integrasi Nilai Budaya Etnis Bugis Makassar Dalam Proses Pembelajaran Sebagai Salah Satu Strategi Menghadapi Era Masyarakat Ekonomi Asean (MEA). Jurnal Teori Dan Praksis Pembelajaran IPS, 1(1), 13-21. https://doi.org/10.17977/um022v1i12016p013

Tanis, H. (2013). Pentingnya Pendidikan Character Building dalam Membentuk Kepribadian Mahasiswa. Humaniora, 4(2), 1212. https://doi.org/10.21512/humaniora.v4i2.3564

Tyson, A. D. (2008). The politics of decentralisation and indigenous revivalism in Sulawesi, Indonesia. $P Q D T$ - $U K \quad \& \quad$ Ireland. Retrieved from http://search.proquest.com/docview/899725217?accountid=13771

Yunus, Nurseha, M. (2020). Culture of Siri' in Learning Akidah Akhlak in MAN Suli Luwu District Budaya Siri' dalam. JIEBAR: Journal of Islamic Education: Basic and Applied Research, 01, 107-120.

Yunus, S. (2020). MODEL PENDIDIKAN BUDAYA BUGIS DALAM PENERAPAN NILAINILAI PLURALISME. JURNAL PENELITIAN, 14(2), 217-248.

Yunus, Y., \& Salim, A. (2019). Eksistensi Moderasi Islam dalam Kurikulum Pembelajaran PAI di $\begin{array}{lllll}\text { SMA. Al-Tadzkiyyah: Jurnal Pendidikan } & \text { Islam, } & \text { 9(2), }\end{array}$ https://doi.org/10.24042/atjpi.v9i2.3622

Yusri, M. (2015). A STUDY ON THE GATHERING STYLES OF INDONESIAN CULTURE Case Study of Tudang Sipulung and Bale- bale in Makassar Islands Osaka University Knowledge Archive : OUKA.

Yustiningrum, R. E., \& Ichwanuddin, W. (2015). Political Participation and Voting Behavior in General Election 2014. Jurnal Penelitian Politik, 12(1), 117-135. 